\title{
Observations on feeding order in a group of Eurasian lynx
}

\author{
Ivan LITERÁK, Martina LITERÁKOVÁ and Jiří KLIMEŠ
}

\begin{abstract}
Literák I., Literáková M. and Klimeš J. 2000. Observations on feeding order in a group of Eurasian lynx. Acta Theriologica 45: 427-430.

In December 1998, a group of three lynx Lynx lynx (Linnaeus, 1758), possibly a female with kittens was observed during two nights at a killed roe deer Capreolus capreolus in the Bukovské Vrchy hills, north-eastern Slovakia. There was an apparent feeding order among the lynx, with the largest eating first and the smallest last. Also, the "play-fight behaviour" was observed.

Faculty of Veterinary Medicine, University of Veterinary and Pharmaceutical Sciences, Palackého 1-3, 61242 Brno, Czech Republic, e-mail: literaki@vfu.cz (IL, JK); Kartouzská 8, 61200 Brno, Czech Republic (ML)
\end{abstract}

Key words: Lynx lynx, behaviour, Slovakia

\section{Introduction}

Direct observations of lynx in the wild are rare due to their secretive behaviour and nocturnal activity and they can seldom last for more than few minutes. In this paper we present two observations lasting for hours of a lynx group feeding at a kill. To our knowledge, no similar observation has been described in the literature. The observations have been done in the Bukovské Vrchy hills in the north-eastern part of Slovakia (Poloniny National Park). At present, 25 lynx are estimated to live in these hills in the mean density of 1 lynx per $32 \mathrm{~km}^{2}$ (Š. Pčola, unpubl.).

\section{Material and methods}

The lynx were observed in the Ruská Kotlina valley in an area of the abandoned village Ruské $\left(49^{\circ} 07^{\prime} \mathrm{N}, 22^{\circ} 21^{\prime} \mathrm{E}, 500 \mathrm{~m}\right.$ a.s.l.). The site of lynx observation was on a small meadow near the Ruský Potok stream surrounded with extensive beech forest. The meadow lay within a shrub and tree habitat under a forested slope. We made all the observations of lynx at the killed female roe deer Capreolus capreolus that we found on 29 December 1998. The kill lay in an open meadow, $20 \mathrm{~m}$ from the nearest shrub and $200 \mathrm{~m}$ from the hunting tower $(5 \mathrm{~m}$ high) from which we observed the lynx. Animals were observed by binoculars $7 \times 50$ during two nights with full moon and temperature $-9^{\circ} \mathrm{C}$ on 29 and 30 December 1998. 


\section{Results}

The first lynx appeared at 21.30 and started to eat the kill on the spot. During the next 10 minutes we spotted another lynx $10 \mathrm{~m}$ and a third lynx $15 \mathrm{~m}$ away from the kill. These two lynx differed in size. They sat and observed the first lynx (the largest) at the kill for a relatively long time. From time to time they got up, walked several metres and again sat or lay down.

The first lynx consumed food continuously for about 50 minutes, then it got up, moved to the wood edge and sat down. The larger one of the two remaining lynx immediately approached the kill and began to eat. At the same time, the smaller lynx joined the lynx that consumed the kill first. The second lynx also consumed the prey continuously for about 50 minutes. The other two lynx did not approach the kill at that time, but sometimes they moved to another spot within $30 \mathrm{~m}$ from the prey and again sat or lay down. A faint miaow-like sound then came from the lynx.

After the second lynx had finished eating and left the kill, the smallest lynx approached the kill and began to eat. The biggest and the medium-sized lynx sometimes moved to another spot. They sometimes sat together; most often, however, they sat several metres apart. After 50 minutes of eating, the smallest lynx withdrew and rested some $10 \mathrm{~m}$ from the kill. Once we observed the biggest and the medium-sized lynx sitting against each other with their faces touching. All the lynx ate in crouched position; occasionally, they elevated the rear part of the body.

Another observation was made the same night at 00.00 when the biggest lynx returned to the kill for about 15 minutes; then it walked to the adjacent wood edge, followed by two other lynx. At the same time, a more intensive, irregularly repeated, miaow was heard from the group of lynx. It sounded like a "keep" at a constant level. Around 00.30 , shadows began to hide the lynx and they were no longer observable by binoculars. Sounds were heard from the lynx at the kill until 1.00 .

In the morning, the rumen of the roe deer was lying outside the rest of the carcass. No other internal organs were found. Only a few muscles remained on the bones. The skin, entire head and distal part of the limbs were untouched.

During the observation next night, the biggest lynx emerged at 20.00 and started to eat the remaining kill. After 20 minutes, two other lynx came from the upper wood edge and sat down about $10 \mathrm{~m}$ from the kill. Sometimes they moved a few metres. Suddenly, the medium-sized lynx closely approached (as if in an attack) the lynx at the kill and then immediately withdrew. The biggest lynx continued to feed for 30-45 minutes and then walked away about $20 \mathrm{~m}$. The medium-sized lynx came to the kill and began to eat. The smallest lynx crouched and pounced against the biggest one, stopping immediately in front of it. We named this behaviour the "play-fight behaviour". During our observation, the smallest lynx "attacked" the biggest lynx six times, and the biggest lynx "attacked" the smallest lynx twice. The smallest lynx held its tail erect during the "play-fight behaviour", while the tails of 
the other lynx hung down. Shortly after the arrival of lynx, one faint miaow was heard. After the medium-sized lynx had finished eating and left the kill, the smallest lynx did not approach the kill and did not eat. All three lynx moved together to the wood edge, walked through the wood and reached the snow-covered plain, which they slowly crossed. They left the kill at 21.30 .

On 31 December 1998, hardly any flesh was left on the bones of the carcass. Only skin, the head and distal parts of limbs remained.

\section{Discussion}

We cannot exclude the possibility that the observed lynx could have been an adult male and female with a kitten, as such observations have been recorded (eg Schmidt et al. 1997). However, in our opinion, it is much more likely that the group we saw were a female with two young that were littermates of different size. At about eight months old, the young achieve approximately $80 \%$ adult size (Hucht-Ciorga 1988). In December, the mother's size still markedly exceeds that of her young. During the period of maternal care (till young are nine months old) the weight differences between littermates can be as much as $2.2 \mathrm{~kg}$, which at the average body weight of young at this age could represent about a $20 \%$ difference (Hucht-Ciorga 1988). Thus there can be marked size difference between littermates.

The observed feeding order in lynx suggests that there is a hierarchy of eating prey among family members with the mother having an access to food first. Also, it seems that the larger kitten dominated over the smaller one. There is a similar tendency in African lions with females being aggressive towards cubs which try to share meal, however, there was no apparent hierarchy in the pride recorded (Schaller 1972).

The biggest lynx (mother) and the medium-sized lynx (young) sitting opposite each other and touching heads can be a manifestation of comfort behaviour, which could have been the cleaning of the head after food consumption - social haircoat care between mother and young observed also in captivity by Stehlík (1984).

Mock attacks of the smallest lynx (young) against the biggest one (mother) and vice versa can be regarded as playful behaviour. In young bred in captivity, no play was observed between mother and young aged 160 days or older (Stehlík 1977). In the event that our young were born in May (Hemmer 1993, Schmidt 1998), we can assume their similar or older age. Mother and young in the wild possibly play till the young is older than they do in captivity.

Sounds uttered by the lynx during our observation resembled synlocalisation calling (Stehlík 1986). The possible function of this call is to strengthen mutual relations within a social group.

Acknowledgements: We are grateful to the staff of Poloniny National Park administration for their support in our field observations. 


\section{References}

Hemmer H. 1993. Felis (Lynx) lynx Linnaeus, 1758 - Luchs, Nordluchs. [In: Handbuch der Säugetiere Europas, Band 5: Raubsäuger - Carnivora (Fissipedia), Teil II: Mustelidae 2, Viverridae, Herpestidae, Felidae. J. Niethammer and F. Krapp, eds]. AULA - Verlag, Wiesbaden: 1119-1167.

Hucht-Ciorga I. 1988. Studien zur Biologie des Luchses: Jagdverhalten, Beuteausnutzung, innerartliche Kommunikation und an den Spuren fassbare Körpermerkmale. Schriften des Arbeitskreises Wildbiologie und Jagdwissenschaft an der Justus-Liebig-Universität Giessen, Heft 19. Ferdinand Enke Verlag, Stuttgart: 1-177.

Schaller G. B. 1972. The Serengeti lion: A study of predator-prey relations. University of Chicago Press, Chicago: 1-480.

Schmidt K. 1998. Maternal behaviour and juvenile dispersal in the Eurasian lynx. Acta Theriologica 43: 391-408.

Schmidt K., Jędrzejewski W. and Okarma H. 1997. Spatial organization and social relations in the Eurasian lynx population in Białowieża Primeval Forest, Poland. Acta Theriologica 42: 289-312.

Stehlík J. 1977. Das Spielverhalten des Luchses Lynx lynx (Linné, 1758). Lynx 19: 67-76. [In Czech with German summary]

Stehlík J. 1984. Das Komfortverhalten des Luchses Lynx lynx (Linnaeus, 1758). Lynx 22: 49-58. [In Czech with German summary]

Stehlík J. 1986. [Ethology and reproduction of the lynx Lynx lynx (Linnaeus, 1758) in captivity]. Dissertation abstract, Ostrava: 1-17. [In Czech with Russian summary]

Received June 1999, accepted 25 September 1999. 